\title{
PENGARUH PERSEPSI DAN MINAT IBU TERHADAP PEMILIHAN JENIS ALAT KONTRASEPSI
}

\author{
${ }^{*}$ Yunik Windarti, Rizki Amalia
}

Kebidanan, Universitas Nahdlatul Ulama Surabaya,"Email: yunikwinda@unusa.ac.id

\section{INFO ARTIKEL}

\section{Riwayat Artikel:}

Diterima: 17-10-2019

Disetujui: 29-07-2020

\section{Kata Kunci:}

Persepsi

Minat

Jenis alat kontrasepsi

\section{A. LATAR BELAKANG}

Indonesia adalah salah satu negara di kawasan Asia Tenggara dengan jumlah penduduk yang banyak, dimana laju pertumbuhan penduduknya sekitar $1,19 \%$ per tahun. Pada Tahun 2030, pertumbuhan ini diperkirakan mencapai 268.074.600 jiwa (Depkes, 2016). Strategi yang baik harus dilakukan oleh

\begin{abstract}
Abstrak: Peningkatan kesejahteraan masyarakat oleh pemerintah melalui berbagai macam program kesehatan. Salah satunya program KB, namun masih banyak pasangan usia subur yang tidak menggunakan alat kontrasepsi, di Jawa Timur 17,18\% PUS tidak menggunakan alat kontrasepsi. Salah satu faktor penyebabnya adalah persepsi yang salah tentang KB sehingga mempengaruhi minat ibu yang mengakibatkan keputusan pemilihan alat kontrasepsi yang tidak tepat. Tujuan penelitian menganalisis pengaruh persepsi dan minat ibu terhadap pemilihan jenis alat kontrasepsi. Desain penelitian analitik dengan tehnik non probability sampling dengan insidental sampling. Populasi akseptor di PMB Vivi Surabaya jumlah 60 orang. Variabel independen persepsi dan minat, variabel dependen jenis pemilihan alat kontrasepsi. Instrumen quesioner, dianalisis uji Regresi Logistik. Hasil penelitian menunjukkan dari 29 responden yang mempunyai persepsi kurang baik, hampir seluruhnya $(86,2 \%)$ memilih alat kontrasepsi jangka pendek. Dari 24 responden yang mempunyai minat rendah hampir seluruhnya $(95,8 \%)$ memilih alat kontrasepsi jangka pendek. Terdapat pengaruh yang signifikan variabel persepsi $(p=0,028)$ terhadap pemilihan jenis alat kontrasepsi dengan nilai OR 4,887 $(95 \% \mathrm{Cl}: 1,190-20,075)$. Terdapat pengaruh yang signifikan variabel minat $(p=0,006)$ terhadap pemilihan jenis alat kontrasepsi dengan nilai OR 20,849 (95\%Cl : 2,431 - 178, 833). Semakin seseorang mempunyai persepsi yang kurang dan minat yang rendah terhadap alat kontrasepsi, maka mereka cenderung memilih alat kontrasepsi jangka pendek.
\end{abstract}

\begin{abstract}
Increasing community welfare by the government through various health programs. One of them is a family planning program, but there are still many couples of childbearing age who do not use contraception, in East Java 17.18\% of EFAs do not use contraception. One contributing factor is the wrong perception of family planning that affects the interests of mothers resulting in inappropriate decisions about the choice of contraception. The purpose of the study is to analyze the influence of mothers' perceptions and interests on the choice of contraception. Analytical research design with non probability sampling technique with incidental sampling. The population of acceptors at PMB Vivi Surabaya is 60 people. The independent variable is perception and interest, the dependent variable is the type of contraception selection. Questionnaire instruments, analyzed by Logistic Regression test. The results showed that of 29 respondents who had poor perceptions, almost all (86.2\%) chose short-term contraception. Of the 24 respondents who had low interest, almost all (95.8\%) chose short-term contraception. There is a significant influence of perception variable $(p=0.028)$ on the choice of contraception with an OR value of 4.887 (95\% Cl: 1.190 - 20.075). There was a significant influence of the variable of interest $(p=0.006)$ on the choice of contraception with an OR value of 20,849 (95\% Cl: 2,431 - 178, 833). The more a person has less perception and low interest in contraception, then they tend to choose short-term contraception
\end{abstract}

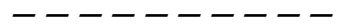

pemerintah untuk meningkatkan derajat kesehatan masyarakat mengingat laju pertumbuhan penduduk yang cukup tinggi tersebut.

Cakupan PUS berdasarkan kepesertaan ber KB di Jawa Timur sebayak 6.316.634 jiwa yaitu dengan rincian $\mathrm{KB}$ aktif (sedang menggunakan alat kontrasepsi) sebanyak 4.150.437 (65,71\%), pernah menggunakan alat kontrasepsi 1.080.799 (17,11\%), dan tidak pernah 
menggunakan alat kontrasepsi sebanyak 1.085.398 (17,18\%). Dari 4.150.437 peserta KB aktif, paling banyak menggunakan alat kontrasepsi suntik yaitu 2.560.928 (61,70\%)(Pusdatin, 2017). Hal ini menunjukkan belum merata penggunaan alat kontrasepsi bahkan 17, 18\% belum pernah menggunakan alat kontrasepsi.

Pengambilan keputusan calon akseptor KB untuk memilih metode kontrasepsi yang tepat, tidak lepas dari faktor perilaku yang dimiliki oleh masing-masing individu tersebut. Bermula dari pengetahuan sehingga menimbulkan sebuah persepsi ibu tentang penggunaan alat kontrasepsi sesuai dengan pemahamannya. Selain itu minat ibu dalam menggunakan alat kontrasepsi juga memungkinkan ibu untuk mengambil keputusan meskipun sebenarnya alat kontrasepsi yang ibu pilih belum tentu tepat secara medis.

Faktor penguat yang memperkuat terjadinya perilaku sehingga ibu memutuskan menggunakan alat kontrasepsi, dalam hal ini adalah dukungan suami dan dukungan petugas pelayanan KB (Notoatmojo, 2007). Sehingga peran tenaga kesehatan (bidan, perawat, dokter, dan lainya) sangat penting dalam memberikan KIE sebelum menggunakan alat kontrasepsi. Tenaga kesehatan hanya mengarahkan, selanjutnya keputusan ada di tangan calon akseptor.

\section{B. METODE PENELITIAN}

Penelitian dilakukan di PMB (Praktik Mandiri Bidan) Vivi Surabaya, dilaksanakan selama 2 bulan yaitu bulan Juli dan Agustus 2019. Desain penelitian yang digunakan adalah tehnik non probability sampling dengan insidental sampling. Populasi dan sampel penelitian adalah semua akseptor yang berkunjung ke PMB Vivi Surabaya. Variabel independennya yaitu persepsi dan minat sedangkan variabel dependennya adalah jenis alat kontrasepsi. Jumlah sampel dalam penelitian ini sebanyak 29 responden.

Pengumpulan data dilakukan secara langsung / data primer. Instrumen penelitian menggunakan kuesioner cetak. Data dianalisis dengan menggunakan SPSS versi 16 secara multivariat menggunakan analisis regresi logistik. Pengaruh dari variabel dependen dan variabel independen ditunjukkan oleh nilai Odds Ratio (OR) dan hasilnya ditunjukkan dengan nilai p.

\section{HASIL DAN PEMBAHASAN}

\section{Hasil Penelitian}

TABEL 1.

Distribusi frekuensi persepsi

\begin{tabular}{|c|c|c|c|}
\hline No & Persepsi & Frekuensi & Persentase \\
\hline 1 & Kurang & 29 & 48,3 \\
\hline 2 & Baik & 31 & 51,7 \\
\hline
\end{tabular}

sebagian besar $(51,7 \%)$ berpersepsi baik.
TABEL 2.

Distribusi frekuensi minat

\begin{tabular}{clcc}
\hline No & Minat & Frekuensi & Persentase \\
\hline 1 & Rendah & 24 & 40 \\
2 & Tinggi & 36 & 60 \\
\hline
\end{tabular}

Tabel 2 menunjukkan bahwa dari 60 responden sebagian besar (60\%) mempunyai minat baik

TABEL 3.

Distribusi frekuensi pemilihan jenis alat kontrasepsi

\begin{tabular}{cccc}
\hline No & Alkon & Frekuensi & Persentase \\
\hline 1 & $\begin{array}{l}\text { Jangka } \\
\text { Pendek }\end{array}$ & 39 & 65 \\
\hline & $\begin{array}{l}\text { Jangka } \\
\text { Panjang }\end{array}$ & 21 & 35 \\
\hline
\end{tabular}

Tabel 3 menunjukkan bahwa dari 60 responden sebagian besar (65\%) memlilih alat kontrasepsi jangka pendek

TABEL 4.

Tabulasi silang persepsi terhadap jenis alat kontrasepsi

\begin{tabular}{|c|c|c|c|}
\hline \multirow[b]{2}{*}{ Persepsi } & \multicolumn{2}{|c|}{ Jenis Alat Kontrasesi } & Jumlah \\
\hline & $\begin{array}{c}\text { Jangka } \\
\text { Pendek } \\
(\%)\end{array}$ & $\begin{array}{c}\text { Jangka } \\
\text { Panjang } \\
(\%) \\
\end{array}$ & \\
\hline Kurang & $25(86,2)$ & $4(13,8)$ & $29(100)$ \\
\hline Baik & $14(45,2)$ & $17(54,8)$ & $31(100)$ \\
\hline Jumlah & $39(65,0)$ & $21(35,0)$ & $60(100)$ \\
\hline
\end{tabular}

Tabel 4 menunjukkan dari 29 responden yang mempunyai persepsi kurang baik hampir seluruhnya $(86,2 \%)$ memilih alat kontrasepsi jangka pendek, sedangkan dari 31 responden yang mempunyai persepsi baik sebagian besar $(54,8 \%)$ memilih alat kontrasepsi jangka panjang

TABEL 5.

Tabulasi silang minat terhadap jenis alat kontrasepsi

\begin{tabular}{lccr}
\hline \multirow{2}{*}{ Minat } & \multicolumn{2}{c}{ Jenis Alat Kontrasepsi } & Jumlah \\
\cline { 2 - 3 } & $\begin{array}{c}\text { Jangka } \\
\text { Pendek } \\
(\%)\end{array}$ & $\begin{array}{c}\text { Jangka } \\
\text { Panjang } \\
(\%)\end{array}$ & \\
\hline Rendah & $23(95,8)$ & $1(4,2)$ & $24(100)$ \\
Tinggi & $16(44,4)$ & $20(55,6)$ & $36(100)$ \\
Jumlah & $39(65,0)$ & $21(35,0)$ & $60(100)$ \\
\hline
\end{tabular}

Tabel 5 menunjukkan dari 24 responden yang mempunyai minat rendah hampir seluruhnya $(95,8 \%)$ memilih alat kontrasepsi jangka pendek, sedangkan dari 36 responden yang mempunyai minat tinggi sebagian besar $(55,6 \%)$ memilih alat kontrasepsi jangka panjang. 
TABEL 6.

Uji regresi logistik

\begin{tabular}{llllll}
\hline \multirow{2}{*}{ Variabel } & & \multicolumn{4}{c}{ Interval } \\
& Wald & OR & \multicolumn{3}{c}{ Keyakinan 95\% Nilai P } \\
\cline { 3 - 5 } & & \multicolumn{3}{c}{$\begin{array}{c}\text { Batas } \\
\text { bawah }\end{array}$} & $\begin{array}{c}\text { Batas } \\
\text { atas }\end{array}$ \\
\hline Konstanta & 11,65 & 0.0 & & & 0.001 \\
& 9 & 21 & & & \\
\hline Persepsi & 4.844 & 4.8 & 1.190 & 20. & 0.028 \\
& & 87 & & 075 & \\
\hline Minat & 7.672 & 20. & 2.432 & 178. & 0.006 \\
& & 849 & & 833 & \\
\hline
\end{tabular}

N Observasi 60

-2 $\log$

likelihood $\quad 52.527$

Nagelkerke

R square $\quad 0,472$

Tabel 6 menunjukkan terdapat pengaruh yang signifikan variabel persepsi $(\mathrm{p}=0,028)$ terhadap pemilihan jenis alat kontrasepsi dan terdapat pengaruh yang signifikan variabel minat $(\mathrm{p}=0,006)$ terhadap pemilihan jenis alat kontrasepsi. Hasil analisis didapatkan nilai OR dari variable persepsi 4,887 (95\%CI : 1,190 - 20,075) dan OR variable minat OR 20,849 (95\%CI : 2,431-178, 833)

\section{PEMBAHASAN}

\section{a. Pengaruh Persepsi Terhadap Pemilihan} Jenis Alat Kontrasepsi

Tabel 4 menunjukkan alat kontrasepsi jangka pendek lebih dipilih oleh ibu yang mempunyai persepsi yang kurang baik terhadap KB. Persepsi mempunyai peran penting dalam membentuk seseorang untuk mengambil keputusan terutama tentang alat kontrasepsi yang di inginkan. Di ketahui dari uji regresi logistik di dapatkan $\mathrm{p}=0,028$ dengan nilai $\mathrm{OR} 4,887$ (95\%CI : 1,190 - 20,075). Nilai $\mathrm{p}=0,028$ membuktikan mempunyai pengaruh yang signifikan antara persepsi terhadap pemilihan jenis alat kontrasepsi. OR 4,887 maka dinyatakan ibu yang mempunyai persepsi baik akan cenderung lebih memilih alat kontrasepsi sebanyak 4 kali lipat daripada ibu yang mempunyai persepsi kurang baik.

Tabel 1 menunjukkan sebagian besar responden mempunyai persepsi yang baik terhadap alat kontrasepsi. Salah satu faktor yang mempengaruhi persepsi adalah kesadaran orang itu sendiri, dimana orang yang mampu mempersepsi diri dengan baik berarti mempunyai kesadaran diri yang baik pula. Orang yang sadar diri akan lebih memperhatikan dan memproses informasi tentang dirinya (Faturochman, 2006). Persepsi terhadap alat kontrasepsi merupakan hasil dari proses aktivitas kejiwaan dimana ibu dapat mamahami dan memberi makna positif atau negatif terhadap alat kontrasepsi yang mana pengetahuan tentang alat kontrasepsi pasti sangat berperan sehingga harapan dan penilaian tentang alat kontrasepsi akan terbentuk.

Rekapitulasi quesioner di dapatkan sebagian besar $(71,7 \%)$ responden adalah multipara. Artinya ibu - ibu sudah lebih berpengalaman daripada yang baru mempunyai anak 1 (primipara). Multipara merupakan seorang ibu yang telah mempunyai anak lebih dari 1 orang. Seseorang yang telah mempunyai pengalaman dalam hal alat kontrasepsi tentu akan mengetahui apakah merasa cocok dengan dengan alat yang digunakan dahulu, sehingga cenderung akan di ulangi lagi pemakaianya. Padahal belum tentu pada saat ini alat kontrasepsi yang di pilih cocok dengan kondisinya sekarang. Hal ini perlu dierhatikan dan membutuhkan penapisan yang benar - benar valid.

Both the American College of Obstetricians and Gynecologists and the North American Menopause Society recommend that women continue contraceptive use until menopause or age 50-55 years(U.S. Department of Health and Human Services, 2013)

\section{b. Pengaruh Minat Terhadap Pemilihan Jenis Alat Kontrasepsi}

Alat kontrasepsi jangka pendek lebih banyak diminati ibu untuk mengatur jarak kehamilanya seperti ditunjukkan tabel 5 yang mana prosentase mencapai 95,8\% atau dikatakan hampir seluruhnya. Artinya keputusan pengambilan jenis alat kontrasepsi tidak lepas dari minat seseorang. Diketahui $\mathrm{p}=0,006$ dengan nilai OR 20,849 (95\%CI : 2,431 - 178, 833). pengaruh yang signifikan antara minat terhadap pemilihan jenis alat kontrasepsi di tunjukkan nilai $\mathrm{p}=0,006$. Ibu yang mempunyai minat tinggi, 20 kali lipat cenderung akan memilih alat kontrasepsi.

Kontrasepsi yang tepat untuk ibu harus memperhatikan situasi dan kondisi ibu, misalnya tentang hal umur. Seorang ibu muda sebaiknya memilih alat kontrasepsi jangka panjang untuk mengatur jarak kehamilanya. Namun untuk ibu yang usia sudah mendekati usia resiko tinggi untuk hamil (menedekati 35 tahun) sebaiknya menggunakan alat kontrasepsi jangka pendek. Berdasarkan data dari 60 responden sebagian besar (75\%) ibu pada usia reproduktif (20 35 tahun) dan berdasarkah hasil rekapitulasi quesioner di ketahui sebagian besar $(53,3)$ responden berusia kurang dari 30 tahun.Usia ini akan lebih baik jika menggunakan alat kontrasepsi jangka panjang misalnya IUD dan implant. Hal ini tidak sejalan dengan hasil penelitian yang menunjukkan bahwa dari 60 responden sebagian besar (65\%) memilih alat kontrasepsi jangka pendek.

Alat kontrasepsi jangka panjang maupun jangka pendek sebenarnya sama sama baik. Dimana tujuan menggunakan alat kontrasepsi adalah mengatur jarak kehamilan sehingga dengan rencana yang baik, diharapkan kesehatan keluarga baik fisik maupun psikologis dapat berjalan dengan baik tanpa timbul ketimpangan dan komplikasi. Namun, dengan penggunaan alat kontrasepsi yang tepat dapat meningkatkan kesehatan ibu dilihat dari berbagai macam aspek.

Minat merupakan sumber motivasi yang mendorong orang untuk melakukan sesuatu yang mereka inginkan bila mereka bebas memilih. Bila mereka melihat bahwa sesuatu menguntungkan, mereka merasa berminat. Ini kemudian mendatangkan kepuasan. Bila kepuasan berkurang, minat pun berkurang. Setiap minat memuaskan suatu kebutuhan dalam kehidupan seseorang, walaupun kebutuhan ini tidak segera tampak bagi orang dewasa. Semakin kuat kebutuhan ini, semakin kuat dan bertahan pada minat tersebut. Selanjutnya, semakin sering minat di ekspresikan dalam kegiatan semakin kuatlah ia. Sebaliknya, minat akan padam bila tidak disalurkan (Hurlock, 2012). 
Menurut Crow \& Crow dalam (Susilowati, 2010) faktor yang mempengaruhi minat seseorang yaitu dorongan dari dalam (internal) dimana dalam hal ini bisa dilihat dari keinginan seseorang untuk ikut program KB. Faktor yang kedua adalah motif sosial yaitu penggunaan alat kontrasepsi ini karena dorongan kebutuhan untuk mengatur kehamilan sehingga secara tidak langsung akan mempengaruhi kesejahteraan terutama perekonomian keluarga. Faktor yang ketiga adalah emosional atau perasaan dimana perasaan senang akan membangkitkan minat dan memperkuat minat untuk memilih dan menggunakan alat kontrasepsi.

\section{SIMPULAN DAN SARAN}

\section{SIMPULAN}

Simpulan dalam penelitian ini dinyatakan sebagai berikut :

a. Terdapat pengaruh secara signifikan antara persepsi terhadap terhadap pemilihan jenis alat kontrasepsi.

b. Terdapat pengaruh secara signifikan antara minat terhadap terhadap pemilihan jenis alat kontrasepsi

\section{SARAN}

a. Bagi Institusi Pendidikan

Mengingat pentingnya pemahaman tentang alat kontrasepsi yang tepat bagi seorang ibu atau akseptor, maka KIE keilmuan tentang keluarga berencana perlu di dalami dan ditekankan lagi tentang penapisan sebelum menggunakan alat kontrasepsi.

b. Bagi Peneliti Selanjutnya

Penelitian lebih lanjut tentang alat kontrasepsi terutama terutama faktor lain yang mungkin signifikan berpengaruh perlu dilakukan penelitian lebih mendalam dengan meminimalkan faktor perancu lainya.

c. Bagi Institusi Pelayanan

Bidan atau tenaga kesehatan lain hendaknya dalam memberikan konseling atau KIE pada calon akseptor khususnya informasi tentang berbagai macam jenis alat kontrasepsi sehingga ibu memahami kekurangan dan kelebihan alat kontrasepsi tersebut sehingga tepat dalam pengambilan keputusan dalam hal memilihnya.

\section{UCAPAN TERIMA KASIH}

Penulis mengucapkan terima kasih kepada Responden, tempat penelitan, segenap Pimpinan, LPPM, dan civitas akademik UNUSA, serta Midwifery journal Unmuh Mataram.

\section{DAFTAR RUJUKAN}

[1] Depkes, 2016. Laporan kinerja kementerian kesehatan tahun 2015. Jakarta : Http: lakip-kemenkes-2015.pdf. Diakses 28 Februari 2019.
[2] Pusdatin, 2017. Data dan Informasi Profil Kesehatan Indonesia 2017. Di akses tanggal 4 Maret 2019. http://www.pusdatin.kemkes.go.id/resources/download/ pusdatin/profil-kesehatan-indonesia/Data-danInformasi_Profil-Kesehatan-Indonesia-2017.pdf

[3] Notoatmojo, 2007. Ilmu Perilaku Kesehatan. Jakarta: Rineka Cipta

[4] Faturochman, 2006. Pengantar Psikologi Sosial. Yogyakarta : Penerbit Pinus

[5] U.S. Department of Health and Human Services, 2013. U.S. Selected Practice Recommendations for Contraceptive Use, 2013.Adapted from the World Health Organization Selected Practice Recommendations for Contraceptive Use, 2nd Edition https://www.cdc.gov/mmwr/pdf/rr/rr62e0614.pdf. Diakses 25 April 2019.

[6] Hurlock, E.2012. Psikologi Perkembangan, Suatu Pendekatan Sepanjang Rentang Kehidupan (terjemahan). Jakarta: Erlangga

[7] Susilowati, M. 2010. Pelayanan Keluarga Berencana. Jakarta: Salemba Medika

\section{PROFIL PENULIS UTAMA}

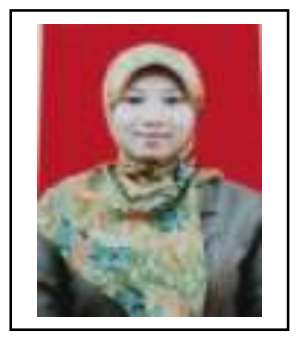

Nama : Yunik Windarti, SST., M. Kes Lahir di kota Ponorogo, dan sekarang domisili di kabupaten Mojokerto Jawa Timur. Lulus D-III Kebidanan di Akbid Yarsi Surabaya tahun 2006 bertepatan dengan konversi menjadi STIKES YARSI Surabaya dan tahun 2013 berkembang menjadi Universitas Nahdlatul Ulama Surabaya (UNUSA). Bekerja mulai 2007 - sekarang pada Prodi D-III Kebidanan Fakultas Keperawatan dan Kebidanan UNUSA 